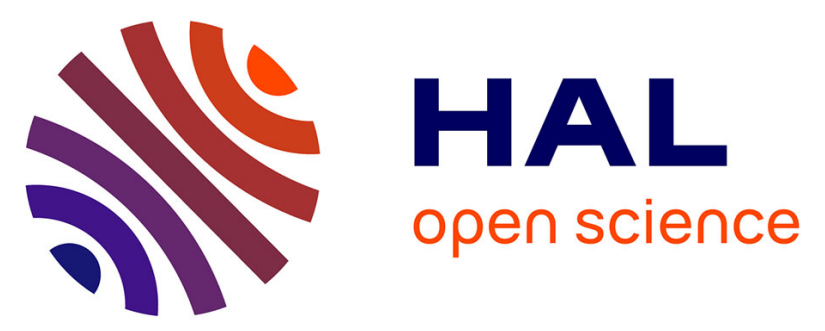

\title{
Depositional Processes of Organic Matter in the Rhône River Delta (Gulf of Lions, France) Traced by Density Fractionation Coupled with $\triangle 14 \mathrm{C}$ and $\delta 13 \mathrm{C}$
}

Flora Toussaint, Nadine Tisnerat-Laborde, Cécile Cathalot, Roselyne Buscail, Philippe Kerhervé, Christophe Rabouille

\section{To cite this version:}

Flora Toussaint, Nadine Tisnerat-Laborde, Cécile Cathalot, Roselyne Buscail, Philippe Kerhervé, et al.. Depositional Processes of Organic Matter in the Rhône River Delta (Gulf of Lions, France) Traced by Density Fractionation Coupled with $\Delta 14 \mathrm{C}$ and $\delta 13 \mathrm{C}$. Radiocarbon, 2013, 55 (2), pp.920-931. 10.1017/S0033822200058070 . hal-02470105

\section{HAL Id: hal-02470105 \\ https://hal.science/hal-02470105}

Submitted on 15 Jun 2021

HAL is a multi-disciplinary open access archive for the deposit and dissemination of scientific research documents, whether they are published or not. The documents may come from teaching and research institutions in France or abroad, or from public or private research centers.
L'archive ouverte pluridisciplinaire HAL, est destinée au dépôt et à la diffusion de documents scientifiques de niveau recherche, publiés ou non, émanant des établissements d'enseignement et de recherche français ou étrangers, des laboratoires publics ou privés. 


\title{
DEPOSITIONAL PROCESSES OF ORGANIC MATTER IN THE RHÔNE RIVER DELTA (GULF OF LIONS, FRANCE) TRACED BY DENSITY FRACTIONATION COUPLED WITH $D^{14} \mathrm{C}$ AND $\mathrm{d}^{13} \mathrm{C}$
}

\author{
Flora Toussaint $^{1,2} \cdot$ Nadine Tisnérat-Laborde $^{1} \cdot$ Cécile Cathalot $^{1} \cdot$ Roselyne Buscail $^{3}$ • \\ Philippe Kerhervé ${ }^{3} \cdot$ Christophe Rabouille $^{1}$
}

ABSTRACT. As a main source of freshwater and particles, the Rhône River plays a major role in the biog eochemical cy cle of organic carbon (OC) in the Mediterranean Sea. To better understand the origin of organic matter and the processes le ading to its export to the coastal sea near the Rhône River, we measured radiocarbon $\left({ }^{14} \mathrm{C}\right)$ and stable carbon is otopes $\left(\delta^{13} \mathrm{C}\right)$ in the sediments of the delta, after density fractionation. In April 2007, 3 sites located along an offshoretransect(A, C, and E) were sampled for surface sediments, and bulk sediment was separated into 4 fractions of different densities $\left(<1.6,1.6-2,2-2.5\right.$, and $\left.>2.5 \mathrm{~g} \mathrm{~cm}^{-3}\right)$. In order to better understand the evolution of the $\mathrm{OC}$ along the transect, we investigated the $\mathrm{OC}$ sources and their evolution for each density fraction. Bulk OC shows a large increase in $\delta^{13} \mathrm{C}$ from $-27.2 \%$ nearshore to $-24.5 \%$ at offshore stations while ${ }^{14} \mathrm{C}$ decreased from $59 \%$ to $-320 \%$. The distribution of $\delta{ }^{13} \mathrm{C}$ with density displayed a convexpattern at all stations. Except for fraction $>2.5 \mathrm{~g} \mathrm{~cm}^{-3}, \delta^{13} \mathrm{C}$ increases by $2.5 \%$ between stations $\mathrm{A}$ and $\mathrm{E}$, indicating a loss of terrestrial sig-nature. The distribution of ${ }^{14} \mathrm{C}$ versus density had a concave pattern at all stations: at a single station, it showed a large het-erogeneity with a difference of 500$600 \%$ between the $<1.6$ and $2-2.5 \mathrm{~g} \mathrm{~cm}^{-3}$ fractions. A decrease in ${ }^{14} \mathrm{C}$ of $-400 \%$ among the different density fractions was observed along the offshore transect. The density fraction $>2.5 \mathrm{~g} \mathrm{~cm}^{-3}$ had less variability, with an average $\delta^{13} \mathrm{Cof}-24.6 \pm 0.4 \%$ 。 and ${ }^{14} \mathrm{C}$ of $-370 \pm 115 \%$. Several processes may explain this distribution: retention in the prodelta of large particles; mineralization of all fractions during the transport and deposition in the delta and shelf sed-iments; and dilution of terrestrial particles in continental shelf pool.

\section{INTRODUCTION}

Estuaries are critical interfaces between the land and sea since they account for a significant portion of the global oceanic carbon budget. Indeed, $40 \%$ of the total particulate organic carbon (POC) delivered

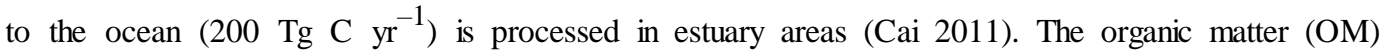
deposited in delta areas undergoes strong burial and mineralization (Hedges et al. 1997). However, large uncertainties remain about the origin of the OC buried, its quantification, and the processes governing OM distribution. The extreme variability in estuaries and coastal areas, on both spatial and temporal scales (e.g. floods, storm events), makes it difficult to assess a reliable long-term OC distribution and budget. Moreover, the OC exported by rivers consists of a mix of many different materials: "recent" OC- derived or biospheric carbon from plant detritus, associated soil OC, autotrophic carbon produced by aquatic plants, and more resistant OC that is eroded from soil and rocks (Galy and Eglinton 2011). Hence, this high variability prevents us from constraining an accurate OC budget by simply measuring the concentration of bulk parameters. Radiocarbon $\left({ }^{14} \mathrm{C}\right)$ and stable isotopes of carbon $\left({ }^{13} \mathrm{C}\right)$ have been proven to be powerful tools for tracing the origin and fate of organic matter and estimating the associated turnover times (Raymond and Bauer 2001). Coupling density fractionation with ${ }^{14} \mathrm{C}$ and ${ }^{13} \mathrm{C}$ measurements offers an opportunity to investi-gate the nature, provenance, and age of OM among density fractions (Wakeham et al. 2009). Indeed, density fractionation allows us to separate the sediment into different fractions with different natures and to determine the interactions between organic matter and minerals (Arnarson and Keil 2001). According to Wakeham et al. (2009), density lower than $1.6 \mathrm{~g} \mathrm{~cm}^{-3}$ consists of large wood debris, density 1.6-2.0 $\mathrm{g} \mathrm{cm}^{-3}$ corresponds to small wood debris and phytoplankton, density fraction 2.0-

\footnotetext{
${ }^{1}$ Laboratoire des Sciences du Climat et de l'Environnement UMR 8212, CEA-CNR-UVSQ Gif-sur-Yvette, France.

${ }^{2}$ Corresponding author. Email: flora.toussaint @ lsce.ipsl.fr.

${ }^{3}$ Centre de Formation et de Recherche sur les Environnements Méditerranéens, UMR 51 10, CNRS, Perpignan, France.
} 
$2.5 \mathrm{~g} \mathrm{~cm}^{-3}$ is constituted by OM minerals-aggregates and finally, the density fraction $>2.5 \mathrm{~g} \mathrm{~cm}^{-3}$ represents the mineral fraction.

The Rhône River is the most important input to the Mediterranean Sea, in terms of water, particle discharges, and OC (Sempéré et al. 2000; Pont et al. 2002). Numerous investigations of the OC cycle in the Rhône River delta have been done to better understand the fate of river OM and bio-geochemical processes of organic carbon degradation in sediment (Pont et al. 2002; Lansard et al. 2009; Cathalot et al. 2010; Harmelin-Vivien et al. 2010; Bourgeois et al. 2011; Pastor et al. 2011a), but the use of ${ }^{14} \mathrm{C}$ is quite novel in this area. Cathalot (2009) first measured ${ }^{14} \mathrm{C}$ coupled with ${ }^{13} \mathrm{C}$ in prodelta bulk sediment. From sampling cruises in different flow conditions, Cathalot et al. (2010) reported that ${ }^{14} \mathrm{C}$ and ${ }^{13} \mathrm{C}$ signatures in the Rhône River delta did not show any significant changes. They argue that this delta is characterized by a strong gradient of mineralization and burial of $\mathrm{OM}$ and an increase in the age of the OM from the river mouth to the continental shelf: modern terrigeneous OM located at the river mouth and an aged OM with a mixed isotopic signature of marine/black carbon on the continental shelf. Hence, they identified several sources of OM: modern terrigeneous OC and continental shelf material, with an important contribution of old OM.

The goal of this study is to better understand the sources and fate of OM in the Rhône River delta. By assessing the reactivity and preservation processes of $\mathrm{OC}$ in the sediment and the distribution of $\mathrm{OC}$ at the river mouth, we aim to better constrain the processes and budgets related to the POC delivered by the Rhône River. To answer these questions, we sampled 3 stations along an offshore transect corresponding to the main path of the Rhone River plume. Along this transect, we determined the distribution of mass, elemental $(\mathrm{C}$ and $\mathrm{N})$, stable carbon, and ${ }^{14} \mathrm{C}$ isotopic composition among 4 density fractions in surface sediments. We then discuss the potential mechanisms that result in the distribution of OM in the Rhone River delta.

\section{MATERIALS AND METHODS}

\section{Study Area}

With a catchment area of $97,800 \mathrm{~km}^{2}$ and a mean water discharge of $1700 \mathrm{~m}^{3} \mathrm{~s}^{-1}$, the Rhône River is the main source of freshwater, sediments, and OM to the Gulf of Lions (Pont et al. 2002). The drainage basin encompasses 4 distinct mountain regions: the Alps, Vosges, Jura, and Massif Central (Ollivier et al. 2011). The input of particulate organic carbon (POC) is dependent on the origin of the watershed and the hydrologic regime. The annual supply of POC is $19.2 \pm 6 \times 10^{4} \mathrm{t}$ $\mathrm{C} \mathrm{yr}^{-1}$ (Sempéré et al. 2000), and water discharge has strong seasonal fluctuations with both low $\left(<700 \mathrm{~m}^{3} \mathrm{~s}^{-1}\right)$ and high inputs $\left(>3000 \mathrm{~m}^{3} \mathrm{~s}^{-1}\right)$. The Rhône River delta (Figure 1) is a sedimentation system, with net sediment accumulation rates ranging from $50 \mathrm{~cm} \mathrm{yr}^{-1}$ in the delta (station A) (Charmasson et al. 1998) to $<1 \mathrm{~cm} \mathrm{yr}^{-1}$ on the continental shelf (stations $\mathrm{C}$ and $\mathrm{E}$ ) (Miralles et al. 2005). The inner shelf of the Gulf of Lions is strongly influenced by the southwestflowing plume of the Rhône River (Raimbault and Durrieu de Madron 2003) (Figure 1).

\section{Sampling}

The sampling cruise (RioMAR) took place on the Rhône River delta in April 2007 during low flow conditions in the Rhône River $\left(800 \mathrm{~m}^{3} \mathrm{~s}^{-1}\right)$. We selected 3 sampling stations located along an off-shore transect with decreasing influence of the river plume (A, C, E) (Figure 1). Station A is located in the delta (1.9 km of river mouth; $431878 \mathrm{~N}, 45107 \mathrm{E}, 24 \mathrm{~m}$ depth), station $\mathrm{C}$ is an intermedi-ate station $(8.6 \mathrm{~km} ; 431628 \mathrm{~N}, 44655 \mathrm{E}, 76 \mathrm{~m}$ depth), and station E is located on the continental shelf (17 km; $431319 \mathrm{~N}, 44191 \mathrm{E}, 75 \mathrm{~m}$ depth). These 3 stations are representative of the depo-sition and mineralization gradients in the main depositional sector (southwestern) of the delta (Lan- 


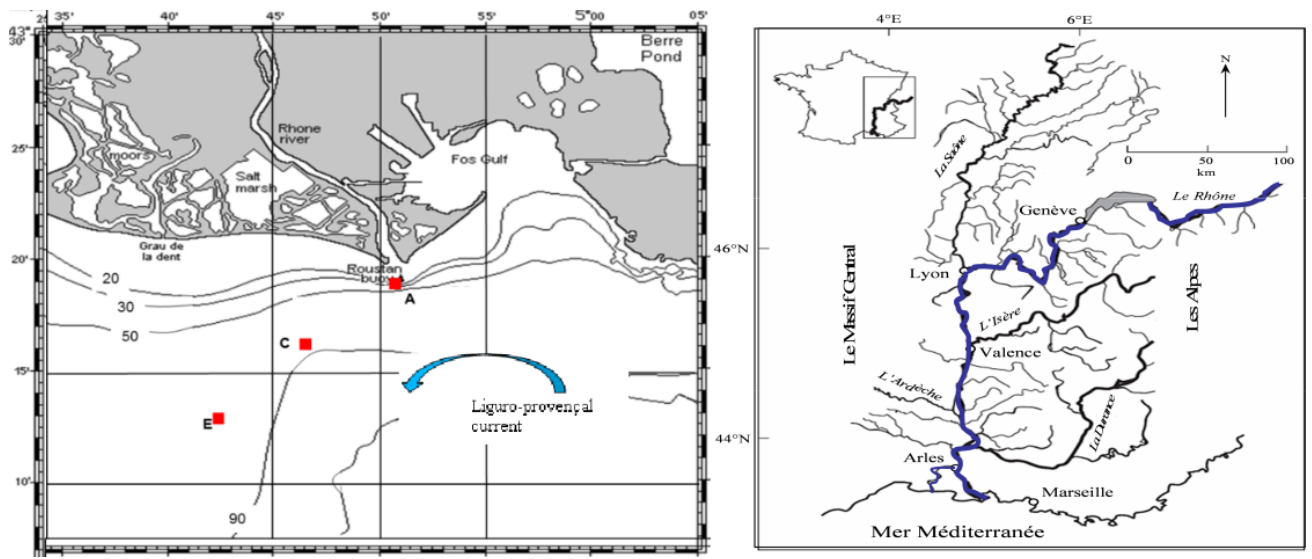

Figure 1 Map of sampling locations: Rhône River mouth

sard et al. 2009; Cathalot et al. 2010). Surface sediment samples were collected with a multicorer MUC 8/100 (Oktopus $\mathrm{GmbH}$ ), which were sectioned and immediately stored on board at $-20 \mathrm{C}$ after sampling. Sediment samples were then freeze-dried in the lab.

\section{Density Fractionation}

Surface sediments $(0-1 \mathrm{~cm})$ were fractionated by density using a sodium metatungstate solution (Arnarson and Keil 2001; Wakeham et al. 2009). Four density fractions were defined: <1.6, 1.6-2.0, $2.0-2.5$, and $>2.5 \mathrm{~g} \mathrm{~cm}^{-3}$. These fractions were obtained using sequential solutions with densities of $1.6,2.0$, and $2.5 \mathrm{~g} \mathrm{~cm}^{-3}$ that were prepared by dissolving sodium metatungstate in Milli- $\mathrm{Q}^{\mathrm{TM}}$ water. Approximately $2-3$ g of dry sediment were precisely weighed, split into two $85-\mathrm{mL}$ centrifuge tubes, suspended in the lightest solution $\left(1.6 \mathrm{~g} \mathrm{~cm}^{-3}\right)$, and mixed on a vortex mixer. Samples were then centrifuged for $8 \mathrm{~min}$ at $2500 \mathrm{rpm}$. The particles in the supernatant were carefully pipetted with a Pasteur pipette from the centrifuge tubes and deposited onto a preburnt, Whatman ${ }^{\mathrm{TM}}$ quartz mem-brane filter QMA. The filter was then washed with Milli-Q water. This process was repeated until no additional particles in the supernatant could be recovered (approximately 6 times). The denser solution, $2.0 \mathrm{~g} \mathrm{~cm}^{-3}$, was then added, and the process was repeated for the last density. Each of the fractionated sediments was then dried at $60 \mathrm{C}$ for 2 days. The fractions were photographed and weighed to verify their masses.

\section{Elemental Analysis, Particle Size Distribution, Stable Carbon Isotope, and ${ }^{14} \mathrm{C}$ Measurements}

Each fraction was acidified with $1 \% \mathrm{HCl}$ for several days to remove the carbonate. They were then rinsed with Milli-Q water and dried at $60 \mathrm{C}$. A first aliquot of treated sediment was precisely weighed (0.07-16.67 mg), and OC content and stable carbon isotope measurements were obtained using an EA-IRMS mass spectrometer (ThermoFinigan Delta+XP) coupled with a CHN analyzer at LSCE. The isotopic compositions were reported using standard $\delta$ notation (\%) with respect to the Vienna Pee Dee Belemnite (PDB) standard, with uncertainties of $\pm 0.15 \%$.

The particle size distribution was measured in the highest density fraction $\left(>2.5 \mathrm{~g} \mathrm{~cm}^{-3}\right)$ with laser diffraction using a Malvern Mastersizer 2000 at IDES. The resulting volume distributions of particles in 100 logarithmically spaced size classes ranged from 0.01 to $2000 \mu \mathrm{m}$. These clas ses were then grouped into a percentile, D50. D50 is the value of the particle size that divides the population exactly into 2 equal halves. 
A second aliquot was precisely weighed (3-300 $\mathrm{mg}$ ) and sealed in quartz tubes under a vacuum with an excess of $\mathrm{CuO}$ and silver wire. Tubes were introduced into a furnace at $850 \mathrm{C}$ for $5 \mathrm{hr}$ to trans-form the organic carbon into $\mathrm{CO}_{2}$. The quartz tubes were then broken under a vacuum. The $\mathrm{CO}_{2}$ that was released was purified and collected (Hatté et al. 2003). Then, the $\mathrm{CO}_{2}$ was reduced to graphite using hydrogen in the presence of iron powder, according to the procedure developed by Arnold et al. (1989). ${ }^{14} \mathrm{C}$ measurements were made with an Artemis accelerator mass spectrometer at the Lab-oratoire de Mesure du Carbone 14 (LMC14 in CEA Saclay). ${ }^{14} \mathrm{C}$ activities were reported in ${ }^{14} \mathrm{C}$ per mil (\%), as defined by Stuiver and Polach (1977). The background values were obtained using ${ }^{14} \mathrm{C}$-dead charcoal (El Akarit) that was treated with sodium polytungstate and were estimated at $0.23 \pm 0.01 \mathrm{pMC}$ (percent modern carbon), equivalent to an age of $41,000 \mathrm{yr}$. The ${ }^{14} \mathrm{C}$ uncertainty values were $\pm 3 \%$ at a confidence interval of 1 .

\section{RESULTS}

\section{Method Validation}

To verify that the density fractionation method is conservative, we first weighed the initial mass of the bulk sample and compared it to the sum of the final masses of all of the fractions. The recovery of all of the fractions compared to the initial sediment weight was $101 \pm 9 \%$. Recoveries higher than $100 \%$ are likely to be due to the incomplete removal of sodium polytungstate. We also calculated the ${ }^{14} \mathrm{C}$ and $\delta{ }^{13} \mathrm{C}$ of the bulk sample using the $\mathrm{OC}$ contribution and the ${ }^{14} \mathrm{C}$ and $\delta{ }^{13} \mathrm{C}$ of each fraction. The $\mathrm{OC}$ contribution from each fraction was calculated as the proportion of the mass of this density fraction multiplied by its $\mathrm{OC}$ content. The results of the calculated bulk samples are close to the measured bulk sediment values. These results confirm that density fractioning is a conservative method.

\section{Sample Observation, Particle Size Distribution}

Figure 2 shows pictures of the 4 different density fractions for the 3 stations (A, C, and E). We observed that the lower fractions $\left(<1.6\right.$ and $1.6-2.0 \mathrm{~g} \mathrm{~cm}^{-3}$ ) were less homogenous along the offshore transect than the higher density fractions. Sediments of the $<1.6 \mathrm{~g} \mathrm{~cm}^{-3}$ density fraction change along the transect with clearly visible fibers and particles resembling a terrestrial wood frag-ment in station A that disappear and the lightest sediment evolves to unidentified black particles in station $\mathrm{C}$ and $\mathrm{E}$. For the fraction $1.6-2.0 \mathrm{~g} \mathrm{~cm}^{-3}$, we note also the disappearance of wood fragments along the offshore transect. The fraction $>2.5 \mathrm{~g} \mathrm{~cm}^{-3}$ was characterized by small particle sizes, with $\mathrm{D}_{50}=15.7$ for station $\mathrm{A}$ and $\mathrm{D}_{50} \sim 10.5$ for stations $\mathrm{C}$ and $\mathrm{E}$ (Table 1).

\section{Elemental Analysis}

All stations displayed the same pattern of mass distribution, with the most important proportion of mass in the highest density fractions $\left(2.0-2.5\right.$ and $>2.5 \mathrm{~g} \mathrm{~cm}^{-3}$ ) (Table 1, Figure 3a). Indeed, $93-$ $97 \%$ of the mass was contained in these 2 density fractions. The bulk sediment and all densities, except the fraction $>2.5 \mathrm{~g} \mathrm{~cm}^{-3}$, were characterized by a decrease in their OC contents along the transect between the mouth of the river and the continental shelf. For bulk sediment, the OC contents decreased from $2 \%$ to $1.1 \%$ at stations A and E, respectively (Table 1, Figure 3b). For the 3 lowest density fractions, a larger decrease in the OC content was observed along the transect (from $19.2 \%$ to $3 \%$, from $23.6 \%$ to $16.6 \%$, and from $4.9 \%$ to $1.9 \%$ for density fractions $<1.6,1.6-$ 2.0 , and $2.0-2.5 \mathrm{~g} \mathrm{~cm}^{-3}$, respectively), while the OC content of the highest fraction $\left(>2.5 \mathrm{~g} \mathrm{~cm}^{-3}\right)$ was very con-sistent $(0.2-0.3 \%)$. 


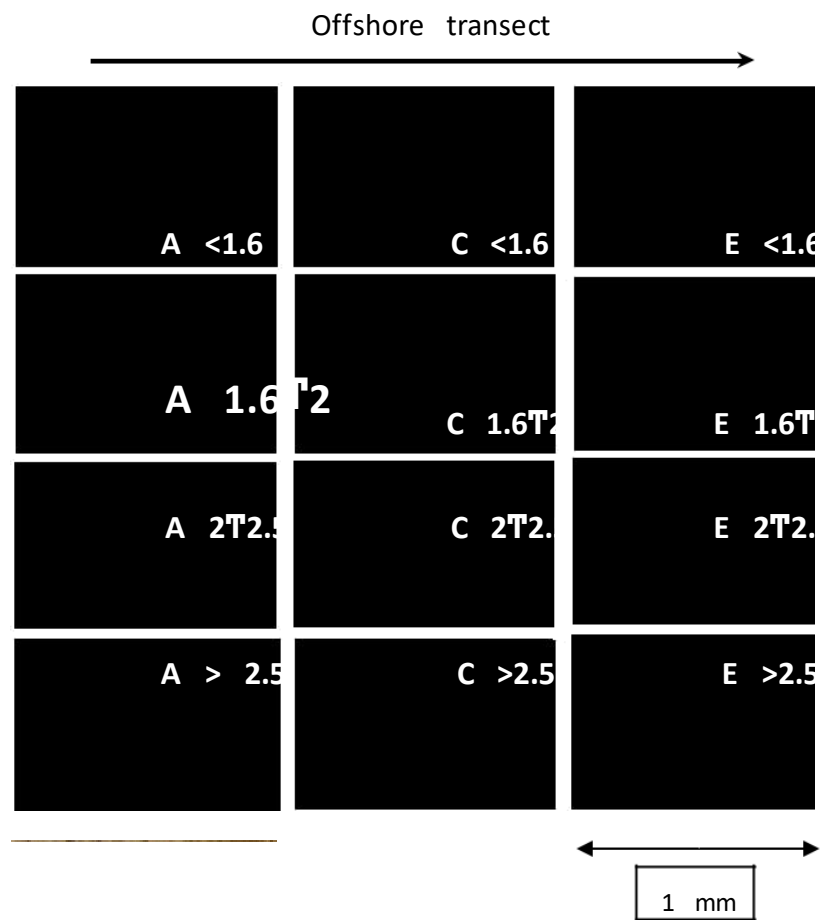

Figure 2 Photographs of the 4 different density fractions at stations A, C, and $\mathrm{E}$.

Table 1 Compositional data for bulk and density fractionated sediments.

\begin{tabular}{|c|c|c|c|c|}
\hline $\begin{array}{l}\text { Fraction } \\
\mathrm{g} \mathrm{cm}^{-3}\end{array}$ & $\begin{array}{l}\% \text { of } \\
\text { mass }\end{array}$ & $\begin{array}{l}\text { OC content } \\
(\% \mathrm{DW})\end{array}$ & $\begin{array}{l}\text { Contribution } \\
\% \text { of OC }\end{array}$ & $\mathrm{D}_{50}$ \\
\hline \multicolumn{5}{|l|}{$\mathbf{A}$} \\
\hline A $<1.6$ & 2.0 & $19.2 \pm 1.2$ & 11.7 & \\
\hline A $1.6-2$ & 5.5 & $23.6 \pm 0.4$ & 38.6 & \\
\hline A $2-2.5$ & 31.6 & $4.9 \pm 0.1$ & 46.4 & \\
\hline $\mathrm{A}>2.5$ & 60.9 & $0.2 \pm 0.0$ & 3.3 & 15.7 \\
\hline Bulk & & 2.0 & & \\
\hline \multicolumn{5}{|l|}{ C } \\
\hline$C<1.6$ & 0.6 & $6.1 \pm 1.4$ & 2.2 & \\
\hline C 1.6-2 & 2.4 & $19.1 \pm 1.6$ & 27.4 & \\
\hline C 2-2.5 & 30.0 & $3.3 \pm 0.1$ & 58.9 & \\
\hline$C>2.5$ & 67.0 & $0.3 \pm 0.0$ & 11.4 & 10.5 \\
\hline bulk & & 1.3 & & \\
\hline \multicolumn{5}{|l|}{$\mathbf{E}$} \\
\hline$E<1.6$ & 2.5 & $3.0 \pm 1.4$ & 5.2 & \\
\hline E 1.6-2 & 1.6 & $16.6 \pm 0.3$ & 18.8 & \\
\hline E 2-2.5 & 49.6 & $1.9 \pm 0.1$ & 65.7 & \\
\hline$E>2.5$ & 46.3 & $0.3 \pm 0.1$ & 10.3 & 10.4 \\
\hline bulk & & 1.1 & & \\
\hline
\end{tabular}


Despite the strong OC content of the density fraction $<1.6 \mathrm{~g} \mathrm{~cm}^{-3}$ and the large mass contribution of the density fraction $>2.5 \mathrm{~g} \mathrm{~cm}^{-3}$, these fractions contributed only a small amount of OC, 2 to $12 \%$ of total OC (Table 1, Figure 3c). In addition, the 2 mesodensity fractions (1.6-2.0 and 2.0 $2.5 \mathrm{~g} \mathrm{~cm}^{-3}$ ) combined represent $84-86 \%$ of the OC contribution (Table 1, Figure 3c). The 2 lightest fractions resulted in a decrease in the $\mathrm{OC}$ contribution with increasing distance to the mouth. The trend was the opposite for the 2 densest fractions, which had increased OC contributions with distance to the river mouth.
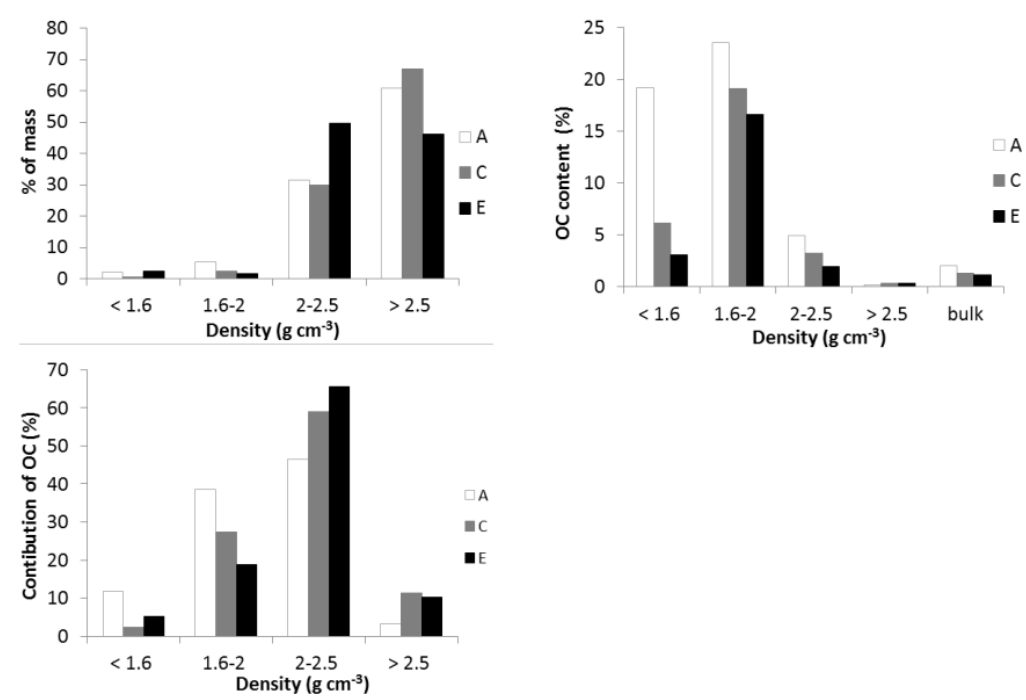

Figure 3 Distributions of measured properties for density fractions and bulk sediment, plotted by density. Distributions of mass (a), OC content (b), and contribution of OC (c).

\section{Stable Carbon Isotopes and ${ }^{14} \mathrm{C}$ Results}

${ }^{13} \mathrm{C}$ OC values of bulk and density fractions ranged from -27.7 to $-24.2 \%$ (Table 2). Figure $4 \mathrm{a}$ depicts the variations in the ${ }^{13} \mathrm{C} O \mathrm{OC}$ values for different fractions at each station, revealing for all fractions the same pattern: ${ }^{13} \mathrm{COC}$ values decreased systematically down to the density fraction $1.6-2 \mathrm{~g} \mathrm{~cm}^{-3}$ and then increased to the densest fractions.
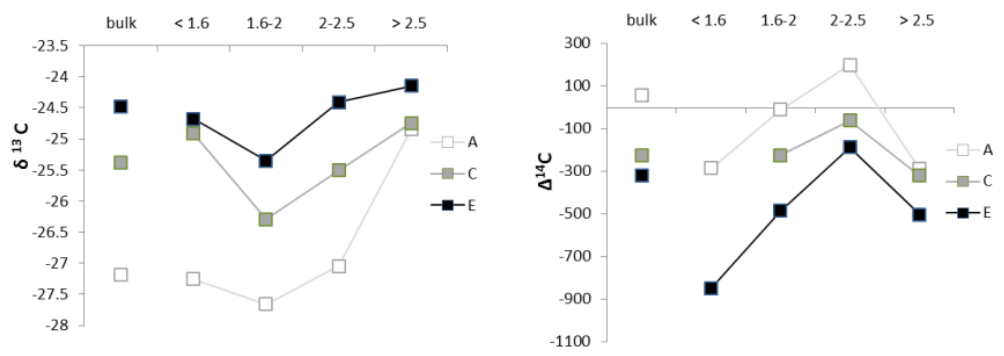

Figure 4 Stable carbon (a) and ${ }^{14} \mathrm{C}$ (b) compositions for density fractions and bulk sediment

The bulk sediment was characterized by a strong gradient in ${ }^{13} \mathrm{COC}_{\mathrm{OC}}$ signature along the offshore transect, with values increasing between stations A $(\sim-27.2 \%)$ and $\mathrm{E}(\sim-24.5 \%)$ (Figure 4a). The signature of station $\mathrm{C}$ was intermediate $(-25.4 \%)$. For each density, we observed the same gradient, 
consisting of an enrichment of ${ }^{13} \mathrm{COC}$ values with increasing distance from the river's mouth (shift of $2.5 \%$ ). The heaviest fraction $>2.5 \mathrm{~g} \mathrm{~cm}^{-3}$ had the lowest gradient $(0.7 \%)$. Its average ${ }^{13} \mathrm{COC}$ value is $-24.6 \pm 0.4 \%$.

${ }^{14} \mathrm{C}$ compositions provide useful information about ages of $\mathrm{OC}$ associated with sediment fraction (Table 2). The bulk ${ }^{14} \mathrm{COC}$ values varied between $+59 \%$ and $-320 \%$ (corresponding to ${ }^{14} \mathrm{C}$ ages of modern age and $3100 \mathrm{yr} \mathrm{BP}$, respectively) along the offshore transect with an aging of OC with increase of distance to the river mouth. The ${ }^{14} \mathrm{COC}$ signature from density fractions is highly variable and ranged from $+200 \%$ to $-848 \%$ (corresponding to ${ }^{14} \mathrm{C}$ ages of modern age and $15,140 \mathrm{yr}$ $\mathrm{BP}$, respectively) (Figure 4b) . The aging of OC with distance of Rhône River delta is also observed in each density fraction. The difference of the ${ }^{14} \mathrm{C}$ OC values of the 2 lowest density fractions along this transect were more important than those of the bulk sample, with a difference between stations A and E of approximately $560 \%, 470 \%$, and $380 \%$ for the density fractions $<1.6$ and 1.6-2 $\mathrm{g} \mathrm{cm}^{-3}$ and bulk, respectively. At all of the stations, the different density fractions had the same variation of ${ }^{14} \mathrm{C}$ OC and ${ }^{14} \mathrm{C}$ ages, first ${ }^{14} \mathrm{COC}$ and ${ }^{14} \mathrm{C}$ ages were enriched and younger than the lower fraction until the fraction $2-2.5 \mathrm{~g} \mathrm{~cm}^{-3}$ (shift 500 or $600 \%$ ) and then in density fraction $>2.5 \mathrm{~g} \mathrm{~cm}^{-3},{ }^{14} \mathrm{COC}$ and ${ }^{14} \mathrm{C}$ ages were depleted, older, and less variable.

Table 2 Isotopes of carbon for bulk and density fractionated sediment. ${ }^{\text {a }}$

\begin{tabular}{|c|c|c|c|c|c|c|}
\hline Fraction $\mathrm{g} \mathrm{cm}^{-3}$ & Lab code & $\begin{array}{l}{ }^{13} \mathrm{C} \\
(\%) \\
\end{array}$ & $\mathrm{pMC}$ & $\begin{array}{r}{ }^{14} \mathrm{C} \\
\text { (yr) }\end{array}$ & $\begin{array}{l}\text { Age } \\
\left({ }^{14} \mathrm{C} \text { yr }\right)\end{array}$ & \\
\hline \multicolumn{7}{|l|}{$\mathbf{A}$} \\
\hline A $<1.6$ wood fragment & Gif $11195 /$ Sac 25112 & & $78.9 \pm 0.3$ & $-211 \pm 3$ & 1900 & \pm 30 \\
\hline A $<1.6$ & Gif 11194/Sac 25111 & -27.25 & $71.4 \pm 0.2$ & $-285 \pm 2$ & 2701 & \pm 30 \\
\hline A $1.6-2$ & Gif $11197 /$ Sac 25114 & -27.66 & $98.9 \pm 0.3$ & $-10 \pm 3$ & 85 & \pm 30 \\
\hline A $2-2.5$ & Gif 11199/Sac 25116 & -27.05 & $119.9 \pm 0.3$ & $200 \pm 3$ & modern & \\
\hline $\mathrm{A}>2.5$ & Gif $11201 /$ Sac 25118 & -24.85 & $71.0 \pm 0.2$ & $-289 \pm 2$ & 2747 & \pm 30 \\
\hline \multicolumn{2}{|c|}{ Bulk calculated with contribution of $\mathrm{OC}$} & -27.23 & & 46 & & \\
\hline \multicolumn{2}{|l|}{ Bulk } & -27.18 & & $59 \pm 2$ & modern & \\
\hline \multicolumn{7}{|l|}{ C } \\
\hline$C<1.6$ & & -24.92 & nd & nd & nd & \\
\hline C $1.6-2$ & Gif $11198 /$ Sac 25115 & -26.29 & $77.6 \pm 0.3$ & $-223 \pm 3$ & 2032 & \pm 30 \\
\hline C 2-2.5 & Gif $11200 /$ Sac 25117 & -25.51 & $93.9 \pm 0.3$ & $-60 \pm 3$ & 504 & \pm 30 \\
\hline$C>2.5$ & Gif $11202 / \mathrm{Sac} 25119$ & -24.75 & $68.0 \pm 0.4$ & $-320 \pm 4$ & 3098 & \pm 40 \\
\hline \multicolumn{2}{|c|}{ Bulk calculated with contribution of OC } & -25.62 & & nd & & \\
\hline \multicolumn{2}{|l|}{ Bulk } & -25.38 & & $-226 \pm 2$ & 2060 & \pm 30 \\
\hline \multicolumn{7}{|l|}{$\mathbf{E}$} \\
\hline $\mathrm{E}<1.6$ & Gif 11204/Sac 25121 & -24.68 & $15.2 \pm 0.1$ & $-848 \pm 1$ & 15,140 & \pm 60 \\
\hline E $1.6-2$ & Gif 11205/Sac 25122 & -25.35 & $51.4 \pm 0.2$ & $-486 \pm 2$ & 5350 & \pm 30 \\
\hline E $2-2.5$ & Gif $11206 /$ Sac 25123 & -24.41 & $81.3 \pm 0.3$ & $-186 \pm 3$ & 1660 & \pm 30 \\
\hline $\mathrm{E}>2.5$ & Gif $11203 /$ Sac 25120 & -24.15 & $49.7 \pm 0.2$ & $-502 \pm 2$ & 5610 & \pm 30 \\
\hline \multicolumn{2}{|c|}{ Bulk calculated with contribution of OC } & -24.57 & & -310 & & \\
\hline \multicolumn{2}{|l|}{ Bulk } & -24.48 & & $-320^{\mathrm{b}}$ & & \\
\hline
\end{tabular}

$\mathrm{a}_{\mathrm{nd}}=$ not determined.

${ }^{\mathrm{b}}$ Other cruise.

\section{DISCUSSION}

Previous studies of density fractionation provided different results: in the Fly River, Goni et al. (2008) reported that the carbon in the sediment fraction $<1.9 \mathrm{~g} \mathrm{~cm}^{-3}$ was characterized by a young age, whereas in other river-dominated systems (Arnarson et al. 2001; Dickens et al. 2006; Wakeham et al. 2009), light carbon $\left(<1.6 \mathrm{~g} \mathrm{~cm}^{-3}\right)$ is often older than carbon found in mesodensity fractions. In 
these deltaic systems, young OC is generally considered the most labile OC and old carbon is refractory, as reactivity is negatively correlated to the turnover time of OM (Charrier et al. 1999; Raymond and Bauer 2001). Our data set reveals significant differences in the composition of sedimentary OM in the Gulf of Lions near the Rhône River prodelta, showing a difference between OM present in the 4 density fractions. Specifically, the contrast between the different density fractions is particularly clear in relation to our microscopic observations and our elemental and isotopic composition data.

To understand the sources of $\mathrm{OM}$ and transformation processes in the delta, we examined the spatial pattern along the offshore transect from station $\mathrm{A}$ to station $\mathrm{E}$ as the main dispersion/transformation axis (Cathalot et al. 2010; Lansard et al. 2009). Four OM reservoirs have been identified in previous studies: Rhône River particles, black carbon material, continental shelf OC, and fresh marine autochtonous OM. The terrestrial OM from the Rhône River has a $\delta^{13} \mathrm{COC}$ centered around $-27 \%$ o (Kerhervé et al. 2001; Harmelin-Vivien et al. 2010), and the ${ }^{14} \mathrm{CoC}$ varies between +150 to $-90 \%$ (Cathalot et al. 2013). The ${ }^{14} \mathrm{C}$ OC is frequently positive during low flow conditions and negative during floods. The $\delta^{13} \mathrm{COC}$ of the $\mathrm{BC}$ in this area varies from -25 to $-24 \%$ (Cathalot et al. 2013), and the ${ }^{14} \mathrm{COC}$ should be between -800 to $-1000 \%$ for this ${ }^{14} \mathrm{C}$-dead material (Goni et al. 2008). The OM from the continental shelf has a $\delta^{13} \mathrm{COC}$ equal to $-24.5 \%$ and a ${ }^{14} \mathrm{CoC}$ of approximately $-400 \%$ (Lansard et al. 2009; Cathalot et al. 2013). For the last end-member, the marine autochtonous OM has a $\delta^{13}$ CoC of approximately $-22.5 \%$ (Darnaude et al. 2004; Harmelin-Vivien et al. 2010) and a

${ }^{14} \mathrm{CoC}$ of $+100 \%$, in accordance with the ${ }^{14} \mathrm{C}$ signature of the DIC (Yechieli et al. 2001). Because the OC of density fractions evolve differently, we discuss each density fraction separately and then combine these evolutions, in a plot of ${ }^{14} \mathrm{C} v s . \delta^{13} \mathrm{C}$ values of all samples and reservoirs, to assess the processes affecting $\mathrm{OC}$ in this area.

In the lowest density fraction, $<1.6 \mathrm{~g} \mathrm{~cm}^{-3}$, a change in the nature of the sediment along the offshore transect is visually observed (Figure 2) with the disappearance of wood fragments. Elemental anal-ysis results confirm this important change over the transect with a decrease of OC content along the offshore transect (Figure 3b) inducing the decrease of the OC contribution. The evolution of the OC present in this light fraction is highlighted by the isotopic analysis. We observe a shift of $\delta^{13} \mathrm{CoC}$ from a terrestrial signature at station A (Darnaude et al. 2004; Lansard et al. 2009; Harmelin-Vivien et al. 2010) to less negative $\delta^{13} \mathrm{C}_{\mathrm{OC}}$ for stations $\mathrm{C}$ and $\mathrm{E}$, approaching the black carbon signature (Goni et al. 2005; Cathalot et al. 2013) (Figure 4a). The ${ }^{14}$ C OC decreases significantly (by 560\%o) between stations A (-285\%o) and E (-848\%o) (Figure 4b), this "aging" of OC in this fraction being combined with a decrease in OC contribution. The wood fragment found in the sediments at station A has a ${ }^{14} \mathrm{COC}$ of $211 \%$ o $\left({ }^{14} \mathrm{C}\right.$ age $\sim 1900 \mathrm{yr}$, Table 2) very close to the signature of the $<1.6 \mathrm{~g} \mathrm{~cm}^{-3}$ density fraction: likely wood fragments contribute most to this density fraction. This age indicates 1) a long residence time for this material in the continent or in the river channel, and

2) a strong degradation/mineralization process for the youngest and most labile terrestrial material during its transport in the river to the coastal zone, as evidenced in Bourgeois et al. (2011) and Pastor et al. (2011b). At station E, the very low ${ }^{14}$ CoC suggests the dominance of old carbon, such as black carbon, which is found by Glaser et al. (2000) in the Brazilian Amazon basin in the low density frac-tion. This finding is supported by the absence of wood fragments and by low lignin contents in the continental shelf sediments (Tesi et al. 2007).

The density fraction $1.6-2 \mathrm{~g} \mathrm{~cm}^{-3}$ shows a similar pattern to that of the fraction $<1.6 \mathrm{~g} \mathrm{~cm}^{-3}$, with a loss of the terrestrial signature along the offshore transect, as evidenced by visual inspection and by changes from station $\mathrm{A}$ to station $\mathrm{E}$ in $\mathrm{OC}$ content, $\delta{ }^{13} \mathrm{COC}$ and ${ }^{14} \mathrm{C}$ OC values (Figure 4). The density fraction 2-2.5 $\mathrm{g} \mathrm{cm}^{-3}$ was the most important contributor of $\mathrm{OC}$ to the sediment at the 3 study sites. At station $\mathrm{A}$, the unexpectedly high value of ${ }^{14} \mathrm{COC}(+200 \%)$ can be explained by the presence of 
OM that had been enriched in ${ }^{14} \mathrm{C}$ during atmospheric nuclear testing in the late 1950 s and early 1960s (Richter et al. 1999). This fraction is visually homogenous along the offshore transect. In con-trast, the isotopic results suggest a transformation of OC that is comparable to the lightest fractions, with a loss of the young terrestrial signature. The relative increase of OC contribution in this density fraction along the offshore transect results from the increase in the mass contribution (Figure 3c). Several studies based on density fractionation suggest that this mesodensity fraction $\left(2-2.5 \mathrm{~g} \mathrm{~cm}^{-3}\right)$ is composed of OM mineral complexes or organo-clay aggregates (Bock and Mayer 2000; Wake-ham et al. 2009) and that this young and reactive OM may be protected by these minerals (Keil et al. 1994; Burdige 2007).

The mass distribution of the different fractions indicated that the sediment was predominantly com-posed of $>2.5 \mathrm{~g} \mathrm{~cm}^{-3}$ material (46-67\%), as found for the Eel margin (Wakeham et al. 2009) or the Washington slope (Dickens et al. 2006). As proposed by these authors, the low OC content of this fraction and its low variability along the export transect suggest that an important part of the sedi-ment is composed of mineral material. Contrary to other density fractions, the isotopic signatures $\left({ }^{14} \mathrm{C}, \delta^{13} \mathrm{C}\right)$ of this sediment fraction at the 3 stations are also very close to that of the continental shelf end-member, which may indicate a common origin. The sediment of this fraction is composed of fine particles $(\sim 10 \mu \mathrm{m})$ that may be easily resuspended and transported. Because of its low OC content, the isotopic signature of this fraction is hidden by the rest of the sediment during the bulk analysis. These observations can be summarized in a graph (Figure 5) of the ${ }^{14} \mathrm{COC}$ vs. $\delta^{13} \mathrm{COC}$ for all samples and their potential sources.

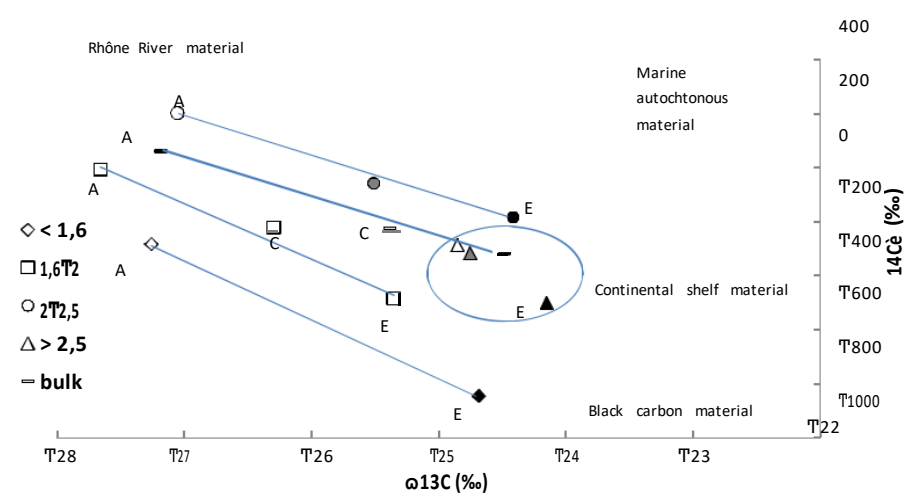

Figure $5{ }^{14} \mathrm{C}$ vs. $\delta^{13} \mathrm{C}$ in density fractions and bulk sediment, with the $4 \mathrm{end}-$ members (Kerhervé et al. 2001; Yechieli et al. 2001; Darnaude et al. 2004; Goni et al. 2005; Lansard et al. 2009; Harmelin-Vivien et al. 2010; Cathalot et al. 2013). The straight lines appearing on the graph connect the data points for each density (i.e. they are not a regression line).

None of the fractions contain fresh marine OM, which is clearly outside the range of the observed data (Figure 5), including the density fraction $1.6-2 \mathrm{~g} \mathrm{~cm}^{-3}$, which should contain marine phytoplankton material according to Wakeham et al. (2009). This is consistent with the weak primary pro-duction in the delta area: the important turbidity and mixture of fresh- and saltwater limits the photo-synthetic activity in the delta (Bourgeois et al. 2011). Furthermore, fresh marine phytoplankton is comprised of labile carbon, which is largely degraded within the water column and would not be found in sediment (Cathalot et al. 2013).

In Figure 5, isotopic signatures of the bulk sediment and mesodensity fractions $\left(1.6-2\right.$ and $2-2.5 \mathrm{~g} \mathrm{~cm}^{-}$ 3 ) range between the OM Rhône River and the continental shelf end-member. The graph clearly 
shows the general aging of all density fractions along the offshore transect, except the $>2.5 \mathrm{~g} \mathrm{~cm}^{-3}$ fraction. The signature of the lowest density fraction $\left(<1.6 \mathrm{~g} \mathrm{~cm}^{-3}\right)$ lies between the Rhône River material and the black carbon end-member. Except for the density fraction $>2.5 \mathrm{~g} \mathrm{~cm}^{-3}$, which seems to be homogeneous material, the lines for each density have similar slopes, suggesting a surprisingly common mechanism of OC evolution from the river to the shelf.

Several processes may explain the OC distribution along the offshore transect within each density fraction. The retention of terrestrial particles, such as large wood fragments in the prodelta, may constitute one of these processes (Radakovitch et al. 1999; Kim et al. 2006; Tesi et al. 2007). Micro-scopic inspection of the 2 lowest density fractions confirms a decrease of these wood fragments along the offshore transect, which is consistent with the isotopic signatures and OC contents of these fractions and the loss of riverine material signature $\left(\delta^{13} \mathrm{C}\right.$ and $\left.{ }^{14} \mathrm{C}\right)$. This retention could be linked to the hydraulic transport mechanisms that preferentially transport the finest material, hence altering the grain size distribution in surficial sediments (Marion et al. 2010) and allowing the preferential deposition of coarser size fractions at the river mouth. However, sediment sorting only partially explains the observed shifts in the isotopic composition because these isotopic shifts are also impor-tant between stations $\mathrm{C}$ and $\mathrm{E}$, which have similar particle size distributions (Cathalot et al. 2010; Bourgeois et al. 2011) and visible textures. This is also the case for the $2-2.5 \mathrm{~g} \mathrm{~cm}^{-3}$ density fraction, which shows a large isotopic shift along the transect (Figure 4) but little change in its fine micro-scopic texture as seen in Figure 2. These observations certainly suggest that other mechanisms are needed to explain the observed pattern.

Another process that can explain the common evolution of all fractions is the mineralization of all fractions (except $>2.5 \mathrm{~g} \mathrm{~cm}^{-3}$ ) during their transport from the river to the continental shelf. Mineral-ization could partially explain the decrease of ${ }^{14} \mathrm{COC}$ along the offshore gradient if selective degra-dation of the most labile and young OC occurs. Lansard et al. (2009) and Pastor et al. (2011b) show that terrestrial OM is less refractory than suggested in previous studies (Hedges et al. 1997). More-over, this degradation may explain the general decrease in OC content during the transport of parti-cles. Previous studies (Cathalot at al. 2010; Lansard et al. 2009) have reported that OC mineraliza-tion is intense in the sediment near the prodelta and decreases in continental shelf sediments. A clear loss of terrestrial young OM is observed in the 2 major OC fractions (mesodensity fractions: $1.6-2$ and $2-2.5 \mathrm{~g} \mathrm{~cm}^{-3}$ ), possibly indicating the selective mineralization of fresh organic compounds. Preservation of black carbon as seen in density fraction $<1.6 \mathrm{~g} \mathrm{~cm}^{-3}$ contributes to the accumulation of aged carbon in shelf sediment (Cathalot et al. 2013). The relative increase in the OC contribution of the 2 highest density fractions can be explained by mineral protection, as hypothesized by Dick-ens et al. (2006) and Burdige (2007).

\section{CONCLUSION}

The density fractionation method enables the separation of different OM types and understanding their evolution. The isotopic signatures of the density fractions show an organized pattern with a loss of the terrestrial signature in all density fractions (except fraction $>2.5 \mathrm{~g} \mathrm{~cm}^{-3}$ ) along the offshore transect. This reflects the interplay of several processes affecting them differentially:

- The retention of large particles, such as wood fragments, in the delta area is possibly an impor-tant process explaining the great visual and isotopic variation in the 2 lowest density fractions.

- A general aging of the material in all fractions, except the fraction $>2.5 \mathrm{~g} \mathrm{~cm}^{-3}$, which is partially linked to mineralization of the labile and young OM, as evidenced by the decrease in OC content in the sediment of the offshore transect and by a large decrease in the ${ }^{14} \mathrm{C}$. Retention of younger particles in the delta also contributes to this aging process. 
- The presence of a reservoir mainly composed of mineral material containing old carbon in the density fraction $>2.5 \mathrm{~g} \mathrm{~cm}^{-3}$, which is present throughout the prodelta and the continental shelf and has an isotopic signature that is similar to continental shelf sediments.

\section{ACKNOWLEDGMENTS}

We wish to thank the captains and crews of the R/V Tethys II and B Bombled for their help with sea work during the cruise. We would like to thank E Kaltnecker, C Hatté, and C Gauthier for ${ }^{14} \mathrm{C}$ and stable isotope measurements; and $\mathrm{O}$ Dufaure and C Colin of IDES (Interaction Dynamique des Environnements de Surface) for the size distribution of my samples. We also extend our thanks to The Compagnie Nationale du Rhône for Rhône freshwater flow. This work was supported by the French National Research Agency, programme "Vulnérabilités: Milieux et Climat," under the grant no. ANR06- VULN-001 to the CHACCRA project, the French INSU-EC2CO program RiOMar.fr, the CEA, the MERMEX project (Marine Ecosystems Response in the Mediterranean Experiment) and the international LOICZ project. This is LSCE contribution number 4602.

\section{REFERENCES}

Arnarson TS, Keil RG. 2001. Organic-mineral interactions in marine sediments studied using density fractionation and X-ray photoelectron spectroscopy. Organic Geochemistry 32:1401-15.

Arnold M, Bard E, Maurice P, Valladas H, Duplessy JC. $1989 .{ }^{14} \mathrm{C}$ dating with the Gif-sur- Yvette Tandetron ac-celerator: status report and study of isotopic fraction-ation in the sputter ion source. Radiocarbon 31(3): 284-91.

Bock MJ, Mayer LM. 2000. Mesodensity organo-clay as-sociations in a near-shore sediment. Marine Geology 163:65-75.

Bourgeois S, Pruski AM, Sun M-Y, Buscail R, Lantoine F, Kerhervé P, Vétion G, Rivière B, Charles F. 2011. Dis tribution and lability of land-derived organic mat-ter in the surface sediments of the Rhône prodelt a and the adjacent shelf (Mediterranean Sea, France): a multi proxy study. Biogeosciences 8:3107-25.

Burdige DJ. 2007. The preservation of organic matter in marine sediments: controls, mechanisms and an imbalance in sediment organic carbon budgets? Chemical Reviews 107:467-85.

Cai W-J. 2011. Estuarine and coastal ocean carbon paradox: $\mathrm{CO} 2$ sinks or sites of terrestrial carbon incineration? Annual Review of Marine Science 3:123-45.

Cathalot C. 2009. Fate and impact of fluvial inputs on continental margins: biogeochemical and environmental importance of the recycling in the sediments of the Rhône River prodelta [PhD thesis]. Université Pierre et Marie Curie.

Cathalot C, Rabouille C, Pastor L, Viollier E, Buscail R, Grémare A, Treignier C, Pruski A. 2010. Temporal variability of carbon recycling in coastal sediments in-fluenced by rivers: assessing the impact of flood in-puts in the Rhône River prodelta. Biogeosciences 7: 1187-205.

Cathalot C, Rabouille C, Tisnérat-LabordeN, Toussain t F, Kerhervé P, Buscail R, Bowles K, Sun M-Y, Tronc- zynski J, Lansard B, Treignier C, Pastor L, Tesi T, Miserocchi S. 2013. The fate of river organic carbon in coastal areas: a study in the Rhône River delta using multiple isotopic $\left(\delta^{13} \mathrm{C},{ }^{14} \mathrm{C}\right)$ and organic tracers. Geochimica et Cosmochimica Acta 118:33-55.

Charmasson S, Bouisset P, Radakovitch O, Pruchon AS, Arnaud M. 1998. Long-core profiles of Cs-137, Cs-134, Co-60 and Pb-210 in sediment near the Rhône River (northwestern Mediterranean Sea). Estuaries 21:367-78.

Charrier J, Bauer J, Druffel E, Coffin R, Chanton J. 1999. Evidence for the ages of assimilated carbon. Limnol-ogy and Oceanography 44(3):730-6.

Darnaude AM, Salen- Picard C, Polunin NVC, Harmelin-Vivien ML. 2004. Trophodynamic linkage between river runoff and coastal fishery yield elucidated by sta-ble isotope data in the Gulf of Lions (NW Mediterra-nean). Oecologia 138:325-32.

Dickens FA, Bladock AJ, Smernik JR, Wakeham GS, Ar-narson ST, Gélinas Y, Hedges IJ. 2006. Solidstate ${ }^{13} \mathrm{C}$ NMR analysis of size and density fractions of marine sediments: insight into organic carbon sources and preservation mechanisms. Geochimica et Cosmo-chimica Acta 70:666-86.

Galy V, Eglinton TI. 2011. Protracted storage of biospheric carbon in the Ganges-Brahmaputra basin. Na-ture Geoscience 4:843-7.

Glaser B, Balashov E, Haumaier L, Guggenberger G, Zech W. 2000. Black carbon in density fractions of an-thropogenic soils of the Brazilian Amazon region. Or-ganic Geochemistry 31:669-78.

Goni MA, Monacci N, Gisewhite R, Crockett J, Nittrouer C, Ogston A, Alin SR, Aalto R. 2008. Terrigenous or-ganic matter in sediments from the Fly River delta-cli-noform system (Papua New Guinea). Journal of Geo-physical Research 113: F01S10, doi:10.1029/ 2006JF000653.

Harmelin-Vivien M, Dierking J, Bănaru D, Fontaine M, 
Arlhac D. 2010. Seasonal variation in stable C and N is otope ratios of the Rhône River inputs to the Mediterranean Sea (2004-2005). Biogeochemistry 100(13):139-50.

Hatté C, Poupeau J -J, Tannau J-F, Paterne M. 2003. Development of an automated system for preparation of organic samples. Radiocarbon 45(3):421-30.

Hedges JI, Keil RG, Benner R. 1997. What happens to terrestrial organic matter in the ocean? Organic Geochemistry 27:195-212.

Keil RG, Montlucon DB, Prahl FG, Hedges JI. 1994. Sorptive preservation of labile organic matter in marine sediments. Nature 370(6490):549-52.

Kerhervé P, Minagawa M, Heussner S, Monaco A. 2001. Stable isotopes $\left({ }^{13} \mathrm{C} /{ }^{12} \mathrm{C}\right.$ and $\left.{ }^{15} \mathrm{~N} /{ }^{14} \mathrm{~N}\right)$ in settling or-ganic matter of the northwestern Mediterranean Sea: biogeochemical implications.Oceanologica Acta 24: S77-S85.

Kim J-H, Schouten S, Buscail R, Ludwig W, Bonnin J, Sinninghe Damsté JS, Bourrin F. 2006. Origin and dis tribution of terrestrial organic matter in the NW Mediterranean (Gulf of Lions): exploring the newly developed BIT index. Geochemistry, Geophysics, Geosystems 7: Q11017, doi:10.1029/2006GC001306.

Lansard B, Rabouille C, Denis L, Grenz C. 2008. In situ oxygen uptake rates by coastal sediments under the in fluence of the Rhône River (NW Mediterranean Sea). Continental ShelfResearch 22:1501-10.

Lansard B, Rabouille C, Denis L, Grenz C. 2009. Benthic remineralization at the land-ocean interface: a case study of the Rhône River(NW Mediterranean Sea). Estuarine, Coastal and ShelfScience 81:544-54.

Marion C, Dufois F, Arnaud M, Vella C. 2010. In situ record of sedimentary processes near the Rhône River mouth during winter events (Gulf of Lions, Mediterranean Sea). Continental ShelfResearch 30:1095-107.

Miralles J, Radakovitch O, Aloisi J-C. 2005. ${ }^{210} \mathrm{~Pb}$ sedi-mentation rates from the Northwestern Mediterranean margin. Marine Geology 216:155-67.

Ollivier P, Radakovitch O, Hamelin B. 2011. Major and trace element partition and fluxes in the Rhône. Chem-ical Geology 285:15-31.

Pastor L, Cathalot C, Deflandre B, Viollier E, Soetaert K, MeysmanFJR, Ulses C, MetzgerE, Rabouille C. 2011a. Modeling biogeochemical processes in sedi-ments from the Rhône River prodelta area (NW Med- iterranean Sea). Biogeosciences 8:1351-66.

Pastor L, Deflandre B, Viollier E, Cathalot C, Metzger E, Rabouille C, Escoubeyrou K, Lloret E, Pruski AM, Vetion G, Desmalades M, Buscail R, Gremare A. 2011b. Influence of the organic matter composition on benthic oxygen demand in the Rhône River prodelta (NW Mediterranean Sea). Continental Shelf Research 31(9):1008-19.

Pont D, Simonnet JP, Walter AV. 2002. Medium-term changes in suspended sediment delivery to the ocean: consequences of catchment heterogeneity and river management (Rhône River, France). Estuarine, Coastal and Shelf Science 54:1-18.

Radakovitch O, Charmasson S, Arnaud M, Bouisset P. 1999. $\mathrm{Pb}-210$ and caesium accumulation in the Rhône delta sediments. Estuarine, Coastal and Shelf Science 48:77-92.

Raimbault P, Durrieu de Madron X. 2003. Research activities in the Gulf of Lion (NW Mediterranean) within the 1997-2001 PNEC project. Oceanologica Acta 26:291-8.

Raymond PA, Bauer JE. 2001. Use of ${ }^{14} \mathrm{C}$ and ${ }^{13} \mathrm{C}$ natural abundances for evaluating riverine, estuarine, and coastal DOC and POC sources and cycling: a review and synthesis. Organic Geochemistry 32:469-85.

Richter DD, Markewitz D, Trumbore SE, Wells CG. 1999. Rapid accumulation and turnover of soil carbon in a rees tablishing forest. Nature 400(6739):56-8.

Sempéré R, Charriere B, Van Wambeke F, Cauwet G. 2000. Carbon inputs of the Rhône River to the Mediterranean Sea: biogeochemical implications. Global Biogeochemical Cycles 14:669-81.

Stuiver M, Polach HA. 1977. Discussion: reporting of ${ }^{14}$ C data. Radiocarbon 19(3):355-63.

Tesi T, Miserocchi S, Goni MA, Langone L. 2007. Source, transport and fate of terrestrial organic carbon on the western Mediterranean Sea, Gulf of Lions, France. Marine Chemistry 105:101-17.

WakehamGS, Canuel AS, Lerberg JE, Mason P, Sa mpéré PT, Bianchi ST. 2009. Partitioning of organic matter in continental margin sediments among density fractions. Marine Chemistry 115:211-25.

Yechieli Y, Sivan O, Lazar B, Vengosh D, Ronen D, Herut B. 2001. ${ }^{14} \mathrm{C}$ in seawater intruding into the Israeli Mediterranean coastal aquifer. Radiocarbon 43(2B):773-81. 